\title{
Guidelines for the spiritual practice of Sabbath-keeping
}

\begin{tabular}{|c|c|}
\hline \multicolumn{2}{|c|}{$\begin{array}{l}\text { Authors: } \\
\text { Pieter G.R. de Villiers }{ }^{1} \text { (1) } \\
\text { George Marchinkowski }{ }^{2} \text { (D) }\end{array}$} \\
\hline \multicolumn{2}{|c|}{$\begin{array}{l}\text { Affiliations: } \\
\text { 'Department of Old and New } \\
\text { Testament, Faculty of } \\
\text { Theology and Religion, } \\
\text { University of the Free State, } \\
\text { Bloemfontein, South Africa }\end{array}$} \\
\hline \multicolumn{2}{|c|}{$\begin{array}{l}{ }^{2} \text { Department of Practical and } \\
\text { Missional Theology, Faculty } \\
\text { of Theology and Religion, } \\
\text { University of the Free State, } \\
\text { Bloemfontein, South Africa }\end{array}$} \\
\hline \multicolumn{2}{|c|}{$\begin{array}{l}\text { Corresponding author: } \\
\text { Pieter G.R. de Villiers, } \\
\text { pgdevilliers@gmail.com }\end{array}$} \\
\hline $\begin{array}{l}\text { Dates: } \\
\text { Received: } 21 \mathrm{~A} \\
\text { Accepted: } 31 \mathrm{I} \\
\text { Published: } 30\end{array}$ & $\begin{array}{l}\text { Apr. } 2021 \\
\text { May } 2021 \\
\text { July } 2021\end{array}$ \\
\hline \multicolumn{2}{|c|}{$\begin{array}{l}\text { How to cite this article: } \\
\text { De Villiers, Pieter G.R., \& } \\
\text { Marchinkowski, G., 2021, } \\
\text { 'Guidelines for the spiritual } \\
\text { practice of Sabbath-keeping', } \\
\text { HTS Teologiese Studies/ } \\
\text { Theological Studies 77(2), } \\
\text { a6771. https://doi.org/ } \\
\text { 10.4102/hts.v77i2.6771 }\end{array}$} \\
\hline \multicolumn{2}{|c|}{$\begin{array}{l}\text { Copyright: } \\
\text { (C) 2021. The Authors. } \\
\text { Licensee: AOSIS. This } \\
\text { is licensed under the } \\
\text { Creative Commons } \\
\text { Attribution License. }\end{array}$} \\
\hline \multicolumn{2}{|l|}{ Read online: } \\
\hline 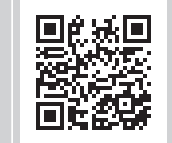 & $\begin{array}{l}\text { Scan this QR } \\
\text { code with your } \\
\text { smart phone or } \\
\text { mobile device } \\
\text { to read online. }\end{array}$ \\
\hline
\end{tabular}

Authors:

Affiliations:

Testament, Faculty of

Theology and Religion,

University of the Free State,

${ }^{2}$ Department of Practical and Missional Theology, Faculty of Theology and Religion, University of the Free State,

Corresponding author: Pieter G.R. de Villiers,

Dates: Accepted: 31 May 2021

How to cite this article: De Villiers, Pieter G.R., \& Marchinkowski, G., 2021, practice of Sabbath-keeping', HTS Teologiese Studies/ Theological Studies 77(2), a6771. https://doi.org/

\section{Copyright:}

(C) 2021. The Authors. Licensee: AOSIS. This work Creative Commons Attribution License.
The commandment not to work and to rest on the Sabbath became a major spiritual practice in Judeo-Christian history. This article will spell out, in a concrete manner, the key spiritual contents of Sabbath-keeping that are relevant for and that determine an authentic, liberating and joyful celebration of the Sabbath. It, thus, contributes to the debate by Christians about the shape and form of what the practice of Sabbath-keeping practice might look like today. This article firstly explains how and why the practice by times became oppressive and abusive, losing its popularity because of a legalistic moralism. It then analyses how the practice in reality is about sanctifying work that reflects its true nature and that contributes meaningfully to human existence. It will focus on how commitment is a necessary beginning to practise the Sabbath before it analyses the dynamic and inspirational nature of Sabbath-keeping as a practice about resting. The article will anchor theological and theoretic reflections concretely in the life experience of faith communities concluding with a discussion about the lightness of the practice that is enjoyed in liturgy, in community, in play and in joyful celebration. The very last part will spell out ecological implications of Sabbath-keeping as one of the latest, exciting forms of Sabbath-keeping.

Contribution: This article responds to the renewed interest in the spiritual practice of Sabbathkeeping. It analyses how the practice lost its popularity because of a legalistic moralism. It will then analyse the lightness of the practice as it is enjoyed in liturgy, in community, in play and in joyful celebration.

Keywords: Sabbath-keeping; Sunday observance; spiritual practices; legalism; moralism; liturgy.

\section{Introduction}

Sabbath-keeping or Sunday observance ${ }^{1}$ was a prominent spiritual practice throughout the history of Judaism and Christianity. ${ }^{2}$ Not only has it been a key characteristic of Judaism up to the present day, but it also played a major role in church history to the extent that a variety of denominations found their identity in terms of the Sabbath as that which distinguished them from mainline churches and that became a major motif in their theological reflection and discourse. ${ }^{3}$ Even within these Sabbatarian traditions, different approaches to Sabbath-keeping developed, ranging from more strict to more open forms of the practice.

There is no fixed model or pattern for Sabbath-keeping: the form of its appropriation depended on the theology, the confessional traditions and the social contexts of those who practised it. Biblical texts already contained various forms of and motivations for Sabbath-keeping. ${ }^{4}$ Christianity differed, for example, in the gradual replacement of the Sabbath in Jewish traditions as the 7 th day with Sunday as the first day of the week because of the resurrection. ${ }^{5}$

1.In this article Sabbath-keeping and Sunday observance are both under investigation, even though they differ in many ways Sabbath-keeping is regarded as an umbrella term that includes Sunday observance, as is evident from the rather loose way in which Sabbath-keeping is used in Christian contexts.

2.The most influential publication in this regard come from Heschel (1951) who wrote a classic study on Sabbath and from Brueggemann (2017). Also striking is the fundamental role of Sabbath in Karl Barth's theology (cf. McCormick 1994:539-552).

3.See https://www.the-ten-commandments.org/sabbathkeepingchurches.html for a list of over 500 churches that are Sabbath-observing churches.

4.For the theoretical reflections that are assumed in this article and on the biblical roots and history of this practice, see De Villiers and Marchinkowski (2020a:429-456, 2020b:175-200)

5.For an extensive discussion of biblical material, see Brueggemann (2017) and the classical publication of Heschel (1951). For various forms of Sabbath-keeping, see Diddams et al. (2004:3) who notes that Christianity struggled with the precise meaning of keeping the Sabbath and as a consequence had a multifaceted approach to it. 
Nevertheless, these forms share some key commonalities that illuminate why it was such a popular practice in many faith communities. A growing number of publications illustrate a keen interest in the nature of this practice. They provide insights into the reasons as to why the practice became unpopular over time. They also reflect the desire to reinvigorate the practice because of its role in the history of the Judeo-Christian traditions and its potential to contribute meaningfully to reinvigorating the practice as a major stimulus to a flourishing lifestyle.

The commonalities in these various forms play an important role in reinvigorating the practice in new contexts. It is, after all, clear that the dynamic nature of past Sabbath-keeping practice creates a space for debating ways and means to design a practice that will resonate in with faith communities in their present situation. This article contributes to what Bass (2005:31) noted when she spelled out the need for clarity about forms of Sabbath-keeping. 'Christians who wish to explore this practice need to have a rich and realistic debate about what specific forms Sabbath practice might take today'. This article will discuss guidelines for the spiritual practice of Sabbath-keeping by analysing problematic approaches that should be avoided and what forms of Sabbath-keeping reflect an authentic celebration of the Sabbath. The article will anchor some theological and theoretic reflections in a concrete analysis of the practice itself and in the live experience of faith communities. It will move from a critical evaluation of a legalistic practice to commitment as a key to practising the Sabbath. It will then, in the last positive part of this investigation, analyse how the practice promotes the sanctification of work, before it will conclude with an explanation of the lightness of the practice that is enjoyed in liturgy, in community, in play and in joyful celebration. The very last part will spell out ecological implications of Sabbath-keeping because it has to do one of the latest, exciting approaches to the practice. ${ }^{6}$

\section{Externalising Sabbath-keeping}

The history of Sabbath-keeping as practice reveals certain approaches that affected it negatively so that it became unpopular for many in faith communities. ${ }^{7}$ From its very beginning, there were certain prescriptions on the keeping of the Sabbath. Over the centuries, however, a multitude of regulations were drawn up to regulate Sabbath-keeping. This included detailed analyses of, for example, the type of work that should not be done on the Sabbath and what would be the right way to spend the Sabbath. ${ }^{8}$ Smith-Gabai and Ludwig (2011:349) note, for example, how the one prohibition

6.This article depends on and reflects Sabbath-keeping in the Bible that the authors investigated in a separate article that will be published in this volume of HTS.

7.Certain practices within Sabbath-keeping pose their own challenges. Marks, Hatch and Dollahite (2017:10), who investigated the Sabbath meal, described some of its challenges. 'External challenges with culture, school, work, and scheduling but also internal (within family) challenges that focused around two repeatedly mentioned "hassles": (a) the demanding preparation and intentionality that is required and (b) the "pulling the demanding preparation and intentionality that is required and (b) the "pulling teeth" and relentless effort that it often takes to engage children's (particularly adolescent children's) participation in the rituals'. This remark indicates the complexity of Sabbath-keeping as a practice with its many dimensions, as will
become clear in the rest of this article.

8.See both Weeks (1981) and Smith-Gabai and Ludwig (2011:349) for other examples. They mention, for example, 39 occupations were prohibited on the Sabbath in the Mishnah and Talmud. of making a fire on the Sabbath is interpreted in orthodox Judaism as forbidding the switching on of lights, computers, cell phones, stoves, televisions and electrical appliances. Orr (s.a.), for example, quotes a pronouncement from 1909 that describes how Puritans held the Sabbath:

All the New England clergymen were rigid in the prolonged observance of Sunday. From sunset on Saturday until Sunday night they would not shave, have rooms swept, nor beds made, have food prepared, nor cooking utensils and tableware washed. As soon as their Sabbath began, they gathered their families and servants around them....and read the Bible and exhorted and prayed and recited the catechism until nine o'clock, usually by the light of one small 'dip candle' only ...'

Taylor (2009) remembers how in the American South one:

[C]ould not wear blue jeans, could not play ball, could not ride bikes, could not go to movies, could not do anything but go to church in the morning and again at night, with a wasteland in between. (p. 127)

Abstinence from certain matters, mostly relating to clothing, entertainment, sporting events and relaxation, was prescribed not only to faith communities, but also to outsiders. People had to behave and dress soberly.

A similar scenario was found in certain times and parts of South Africa, where Calvinist churches prescribed attendance of church services as the main activity of Sunday observance. The threat of censure hung over those who did not participate or neglected attendance. These services were often stern in tone and austere in character. The rest of the day comprised regimented rest, family gatherings and the proverbial Sunday lunch. Other social activities like sport, dancing, swimming, needlework and baking were not allowed. Shops and entertainment like cinemas were forbidden. This phenomenon of strict observance also in secular contexts was possible because of the collaboration of church and state that placed legislation in place to enforce Sabbath-keeping.

Weeks (1981:277), for example, also writes how, even as late as in 1958, the Southern Presbyterian Assembly officially investigated Sunday observance and noted how the church had 'made of Sabbath theology "a dull and dreary series of don'ts"'. Many were bored by the practice and saw Sabbath-keeping as a burden. For them, the practice had a legalistic nature, ${ }^{10}$ generating a formalistic, externalist observance without any transformative impact.

Even more disconcerting was how this practice was also compromised by the threats and violence with which it was enforced. In some instances and places, those who resisted were regarded as violators and punished in the most extreme manner. Weeks (1981:268), for example, also notes how Virginia in colonial North America provided harsh

9.Quoted in Earle $(1909: 254,257)$. It is interesting to note how the churches already at that early stage criticised the neglect of Sunday observance because of commercial interests and activities.

10.See especially Diddams et al. (2004) for a fuller discussion of negative experiences of Sabbath-keeping. 
punishments for Sabbath-breaking: a first offender lost a week's pay, got whipped for a second offence and was even given the death penalty for a third transgression. ${ }^{11}$ This rigidness should not come as a surprise, given the gruesome episode reported in Numbers 15:32-36, where the people arrested a man because he picked up sticks on the Sabbath and were instructed by God to stone the man to death.

As a result of this strict and threatening regimentation, Sabbath-keeping often became a matter of observing a set of rules rather than an opportunity to grow in faith and experience abundant living. In due course, Sabbath-keeping was upheld mostly by marginal and orthodox groups, often motivated by their particular ideological, fundamentalist bent. Their legalistic understanding of the practice is fed by their literalist interpretation of the Bible, so that killing violators would not be such a far-fetched idea to them.

The practice can, in fact, be counterproductive. Bass (2005:372), pointing out the devastating consequences of a moralistic Sabbath-keeping, remarked how failure can generate deep feelings of guilt and incompetence. Legalism and moralism with their transactional quality contradict the liberating nature of the commandment to keep the Sabbath. In this as in everything else, Christians seemingly rely less on the grace of God than on their good works.

It is tragic that Sabbath-keeping is compromised by moralism and legalism because the idea to abstain from work for 1 day has an inherent beauty and even a universal appeal. There is, namely, generally a popular desire to suspend the hectic lifestyle of the week at least for a short time, especially in a profit-driven, materialistic culture. Many people desire to counter through such a day the harshness of consumerism and materialism. This appreciation is discernible even in judicial contexts: McLaughlin (2017) investigated court cases in the United States of America in which a Sabbath day was regarded as a common good for humanity, and, consequently as a human right. The court ruled, however, that whilst it is permissible for such a day of rest to be legislated in states, it is not allowed to do so on religious grounds. ${ }^{13}$ This exemplifies how the idea of a day of rest is appreciated within a secular context.

A disciplined, regulated practice of Sabbath-keeping need not be regarded negatively. Whilst outsiders regarded such prohibitions as restrictive, other communities found them liberating because of their sensitivity not to unwittingly compromise the sanctity of the day. It can indicate a strong desire to keep the Sabbath holy. It also had a protological character, as faith communities remained conscious of their origins, spelled out in the creation narrative and desired

11.This was also the case elsewhere. See Parker (1984:340) about the death penalty that was applied to Sabbath-breakers in England. Legislation by civil authorities and states on Sunday commerce and activities also contributed to the legalism.

12.'To master the capacity to observe the Sabbath no matter what, or to suffer guilt after failing to do so each week, is pointless'.

13.The court's ruling implied that nothing prevents faith communities to keep and promote such a day as Sunday observance. that their practice reflect the divine rest. They also held onto its eschatological nature: the Sabbath reflected for them the hope of future bliss and eternal rest in paradise. Orr (s.a.):

Sweet to the Pilgrims and to their descendants was the hush of their calm Saturday night, and their still, tranquil Sabbath, - sign and token to them, not only of the weekly rest ordained in the creation, but of the eternal rest to come. ${ }^{14}$

Also striking was the consistently communal nature of the practice: it provided the opportunity to promote family life, to be with others in the close family context and to engage in deeds of mercy and compassion. All this confirms that the regulatory approach to Sabbath-keeping was intended to promote its spiritual, transformative nature. It is, therefore, a pity that these good intentions did not always translate into practice and prevented a moralistic approach that some experienced as abusive.

The above remarks describe the negative approach to Sabbath-keeping that degraded it to an externalised, legalistic practice. In the following sections, some perspectives will be mooted that characterise a practice that is transformative and life-enhancing. Reinvigorating Sabbath-keeping as a spiritual practice is empowered by the basic insight that it functions within the divine-human relationship. Biblical texts, in which the institution of the Sabbath is discussed, describe the Sabbath as a divine gift that empowers humanity to continually grow deeper into the relationship. ${ }^{15}$ This divine-human relationship is dynamic to its core: it is about the ongoing transformation of humanity in its response to the divine touch. From them, one can extrapolate certain motifs and themes that illuminate Sabbath-keeping as a practice, as will be discussed now.

The remarks in this section can be illustrated in a practical manner by the experience of Quartey, a Ghanaian Adventist who wrote (2018) about Sabbath-keeping how he was upset when he visited his church denomination in Sweden where the pastor allowed the youth to play soccer and swim on the Sabbath after attending a church. He reports how the pastor listened to his 'sanctimonious' speech, put his arm around his shoulders and whispered:

[M]atthew, occasionally, like today, we go to the beach on Sabbaths. It is one of various activities we organise to keep our youth together on Sabbaths, in a church atmosphere. We've decided this is better than risking having them be by themselves in the streets. (n.p.)

He regarded this episode as a meaningful lesson in the 'power of local solutions' and observes how he understands that Sabbath rest should not devolve into an oppressive burden of rules. He also notes (2018:s.p.), interestingly enough, given his background and affiliation, how, even in a conservative context, there are various ways of keeping the Sabbath.

14. Quoted in Earle (1909.254.257). Churches already at that early stage criticised the neglect of Sunday observance because of commercial interests and activities, thus drawing attention to the consumerist context that influenced faith communities.

15.See Waaijman (2002) and (2007) for this understanding of spirituality. 
The reason for these stories about Sabbath dos and don'ts is to highlight the fact that even though the Sabbath is the most unifying Adventist doctrine, we don't endorse a uniform way of observing it. We accommodate our differences. But for many amongst us, what we do or fail to do on Sabbath is still fraught with guilt and doubt.

\section{Beginnings: Choosing and committing to Sabbath-keeping}

Biblical texts imply that the Sabbath is instituted by God, reflects the character of God and has a consistent soteriological function. As a divine gift to humanity, it intends to liberate humanity and empower them to live a fulfilling life. It is who God is and what God gives, which empowers humanity to practise Sabbath-keeping. The gift is at the same time also about how the image of God, who rested after the creation days, inspires and motivates the Sabbath-keeping. ${ }^{16}$

In the divine-human relationship, humanity responds to the awe-inspiring touch of God by an openness and a desire to remain in the divine presence. This response requires attentiveness, commitment with the heart, mind and will and is pursued through discipline and with perseverance. ${ }^{17}$ Unlike breathing, sleeping and eating, Sabbath-keeping is then about a decision to set aside and commit to one day in seven as 'a Sabbath to the Lord' (Ex 20:8). It is an ongoing decision because the Sabbath is a day to be 'remembered', as noted in Exodus 20:8, that is, to pursue consciously as a spiritual gift. To keep Sabbath is, therefore, to practise receptivity. This implies a certain passivity, being aware of a deeper dimension of human existence and waiting attentively and with an openness and sensitivity for who God is and what God does. It is about listening, speaking, committing and dedicating to God. And yet, in the passive openness, there is action. Whoever listens and attends at the same time receives the fruits of the Sabbath. ${ }^{18}$

To understand this fully, it is necessary to reflect more consciously on the nature of decision, borrowing some insights from psychology. Choosing and deciding determine one's happiness, as has been emphasised in positive psychology as

16.This applies what Waaijman (2008:13) describes as, "[ $t$ ]he two poles interlock: for humans the divine emanations form the way back to God; God's abundant mercy takes shape in human works of mercy; God's holiness is received by believers in the sanctification of their life'.

17.Waaijman (2008:14): 'The relation between God and man is a process extending from the very first awesome touch to respectful love; from living in the commonplace world to being completely consumed in the reality of God; from the ultimate emanation of God to a state of attachment to the Infinite; from original wholeness to complete maturity. The original wholeness of man looks forward to a complete surrender-in-love; the human spirit finds its completion in union with the Spirit of God; the divine core reaches its resting place when it breathes along with the self-giving of the Father'. The gift and response are intricately linked. Christian theologians historically have agreed that claims of direct causality between practice and faith are dubious and have denied that engering in specific behaviours can instil or increase God's gift of faith (Bass 2005:26).

18.See Waaijman (2008:13): 'As a result of this reciprocity human conduct is both active and passive: God's mercy is received in deeds of mercy; the fear of God trembles at the Secret to which it reaches out; the knowledge of God is God-given knowledge'. the scientific study of the flourishing of individuals and communities. ${ }^{19}$ This new research field takes its foundational values from religion and ancient philosophers such as Aristotle (McMahon 2018; Specter 2018). ${ }^{20}$ Aristotle believed that the highest form of happiness is eudaimonia, which is defined as living a virtuous and purposeful life by doing and intentionally choosing instead of focusing solely on feelings of positive emotions. He believed that the more frequently one chooses to practise skills, such as cooking or showing kindness, the more one gains knowledge, meaning and purpose. ${ }^{21}$

Aristotle, thus, illuminates the importance of choice and commitment. This is true within a Jewish-Christian context of the choice and commitment of Sabbath-keeping. When one consciously embraces a life-giving practice like Sabbath-keeping, one grows spiritually. The practice becomes a way of life. It is about an ongoing decision, repeated regularly. Sabbath-keeping in the strict sense of the word is about a process with which one engages on a weekly basis thereby gaining in knowledge, meaning and purpose (Waaijman 2006:13-14).

This aspect reveals the impact of committing and choosing. It reflects human agency, which helps people to overcome feelings of hopelessness and doubt, and to find meaning in their situation. They become more involved in the practice because, as Diddams, Surdyk and Daniels (2004:7) note, choice and commitment are a motivating factor for devoting an 'entire day to Sabbath keeping without negatively impacting their lives'.

\section{Sanctifying work}

Biblical passages and faith traditions associate Sabbath-keeping mostly with not working on the Sabbath (Bass 1997:86, 2000:67-70; Olson 2008:28). 'Work' in this context refers to normal, daily activities through which one earns a living and which are conducted on all days of the week, except on the seventh day.

Sabbath-keeping is, however, not merely about abstaining from work as it is done during the week. Work is often viewed as toiling, as burdensome labour, as, for example, already in Ecclesiastes 3:9-13: 'what does the worker gain from his toil?' (cf. also Gn 3:17; 5:29 and Mt 11:28). This negative understanding of work can be found in many discussions of Sabbath-keeping, in which faith communities

19.In early Judaism happiness related to following the divine laws (McMahon 2018) To serve God will promote well-being. Happiness is also found through engaging critically with the theology implicit in a practice that helps also to take decisions. Biblical texts, sermons, hymns, theological texts and everyday conversations all contribute to this process. Learning to discern and negotiate the specific contours of faithful practice in conversations with others in particular social contexts is especially important (Bass 2005:36)

20.Ancient theories of well-being sparked a new conversation in 1998 when Martin Seligman, in his role as President of the American Psychological Association (APA), declared positive psychology as the theme of his presidential term (Peterson 2006). Through years of researching depression, Seligman (2006) realised that there was a lack of balance in the field of psychology. The field had been concentrating most of its research efforts on the causes of or relief from misery and pathology and paid little attention to studying what makes people and entities thrive. The relevance of this approach is evident in the non-legalistic and wholesome nature of Sabbath-keeping.

21.See Specter (2018) for a full discussion. 
viewed it as a curse and as punishment for sin. In secular society in general, work satisfaction seems to be low, ${ }^{22}$ which is why weekend is greeted with so much joy as the escape from the burdens of the work-week.

Sabbath-keeping does provide another perspective on work. As Barnes (2013:4) noted, however, Ecclesiastes 3:13 implies that work has intrinsic value, because it speaks of the gift of God that people may eat and drink and find satisfaction in all their toil. This is an indication that Sabbath-keeping is not about escaping from work. Sabbath-keeping assumes the importance of work as an essential part of creation and of recreation. Rather than downgrading or denigrating work, Sabbath-keeping reflects an appreciation of work, but then it spells out its specific place in human life. This positive notion of work is in line with the description of God as a Worker who finds joy in the 6 days of creation (Gn 2:2-3). Humanity, as created in the image of God, shares the motif of worker and can regard work as meaningful. ${ }^{23}$

The work week of 6 days (e.g. Ex 20:9; 23:12; 31:15; 34:21 etc.) is, however, qualified by and sanctified by Sabbath as its ultimate end. Abstaining from work is, furthermore, not merely only about relaxing or resting. To refrain from work creates a place in which one can distance oneself from work in order to reflect on its meaning within the divine order and on what lies beyond it. Sabbath-keeping then breaks the monotony of providing one's basic needs and of seeking selfinterest. It addresses the endemic tendency to find meaning in work as if it represents the real meaning of life. Identity is not to be found in a profession, in status and material benefits that ultimately fulfil only some needs. Such a skewed focus on work, on external matters, activities and relationships leaves one unfulfilled, and is often a source of anxiety. Bass (2005:36) helpfully observes that Christians acknowledge in Sabbath-keeping that the world does not depend on their own capacity to perform and brings awareness that these are not under their control.

The practice opens a space for conscious reflection on the hidden meaning of all one's preoccupations, occupations and endeavours. It helps one discover what else is involved in one's existence that life is about more than work. The Sabbath, therefore, breaks what can easily become a pathological work rhythm that inhibits the mind and closes the eyes to the

\footnotetext{
22.The negative experiences about work is reflected in the following statistics: a Gallup poll in 2017 found that 'worldwide, the percentage of adults who work full time for poll in 2017 found that 'worldwide, the percentage of adults who work full time for
an employer and are engaged at work - they are highly involved in and enthusiastic an employer and are engaged at work - they are highly involved in and enthusiastic
about their work and workplace - is just $15 \%$. One of the most surprising about their work and workplace - is just $15 \%$. One of the most surprising
differences is that the proportion of engaged employees in Western Europe - one differences is that the proportion of engaged employees in Western Europe - one
of the world's most economically developed regions - is even lower than the global average' (https://fundacionprolongar.org/wp-content/uploads/2019/07/State-ofthe-Global-Workplace_Gallup-Report.pdf), consulted 16 April 2021. A Gallup poll in July 2020 showed that $54 \%$ of workers in the United States of America are 'not engaged' - 'they are psychologically unattached to their work and company. These employees put time, but not energy or passion, into their work. Not engaged employees put time, but not energy or passion, into their work. Not engaged employees typically show up to work and contribute the minimum effort required. They're also on the lookout for better employment opportunities and will quickly leave their company for a slightly better offer'. (https://www.gallup.com/ workplace/313313/historic-drop-employee-engagement-follows-record-rise.aspx notes how stress, physical and mental health affects job satisfaction.

23.See Barnes (2013) for an informative discussion about biblical motifs for work and their practical application for contemporary ethics.
}

deeper energy that drives one's existence. It also opens the eyes to what else can bring rest and joy in one's life.

Ultimately then, Sabbath-keeping sanctifies work by requiring that it should be interrupted by a day of rest, but, more importantly, by creating the opportunity to use such a day to reflect on its place and role regarding the deeper values of human life and on ultimate reality. It is about avoiding an overload of work that prevents one from living a meaningful life or from seeking self-promotion.

Ironically then, Sabbath-keeping that calls for breaking the cycle of daily labour also confirms the goodness of work. This is further confirmed by the covenantal framework in which the Sabbath-commandment is integrated: both Sabbath-keeping and work relate to the gift of creation and recreation. It also implies that work should not have a transactional nature, but it should be approached as an opportunity to find a fulfilling and flourishing life.

These remarks about the nature of work are of seminal importance for the present situation of faith communities in the corporate world, but it also illuminates the need to reconsider their attitude towards work. Marschke, Preziosi and Harrington (2009) investigated various aspects of what is known as workplace spirituality and expressed concerns about the consequences of the present state of affairs in which work is experienced as a burden. They noted the beginnings 'since the late 1990's, partly because of the enormous cost of disregarding human resource standards as they relate to business practices', and refer to major scandals that reflect:

[L]ack of character, arrogance and immoral values amongst top management that inflicted widespread emotional, organisational and financial devastation to employees, customers and stockholders, as well as penalties and imprisonment for their morally bankrupt leadership. (p. 33)

They conclude that the situation can be transformed by workplace spirituality that empowers people to commit more positively to their work.

In addition, Exodus 16 points to another limitation of work: what counts is to pursue a modest lifestyle. Mindful of the soberness illustrated in Exodus 16 and in the life of Christ (Vorster 2011:188-189), Sabbath-keeping reminds one of being satisfied with what is 'enough'. Through Sabbath-keeping with its teaching of the sufficiency of being provided for, one is prompted to avoid the reckless pursuit of wealth that leaves others impoverished. In this way, a very different attitude towards work is promoted by Sabbath-keeping.

The spiritual values that will be empowering are described by Marques (2005:87) who also investigated spirituality in the workplace. The definition that contains motifs and insights resonates with biblical texts in which Sabbath-keeping is discussed..$^{24} \mathrm{He}$ described the following values:

24.See the discussion of De Villiers and Marchinkowski (2021) for Sabbath-keeping and its spiritual values that will appear elsewhere in this volume of HTS. 
Spirituality in the workplace is an experience of interconnectedness, shared by all those involved in a work process, initially triggered by the awareness that each is individually driven by an inner power, which raises and maintains his or her sense of honesty, creativeness, proactivity, kindness, dependability, confidence and courage, consequently leading to the collective creation of an aesthetically motivational environment characterized by a sense of purpose, high ethical standards, acceptance, peace, trust, respect, understanding, appreciation, care, involvement, helpfulness, encouragement, achievement and perspective, thus establishing an atmosphere of enhanced team performance and overall harmony, and ultimately guiding the organisation to become a leader in its industry and community, through its exudation of fairness, cooperativeness, vision, responsibility, charity, creativity, high productivity and accomplishment.

Sabbath-keeping has the potential to promote and inculcate many of these spiritual values that can become part of or characterise a workplace spirituality. Sanctifying work through Sabbath-keeping can contribute significantly to a society that refuses to accept corruption as a normal part of life and that wishes to promote a fulfilling and meaningful lifestyle, as will become clearer in the following sections.

\section{The lightness of Sabbath-keeping}

Sabbath-keeping often suffered under a heaviness that gave it a sombre, dark character, especially because it was seen as a negative practice that sought to avoid what will look like work on Sunday through a fixed set of rules. Behind this, there was a particular theological mindset that accepted that the holy has to do with the divine sphere that stands in tension with the mundane. The Sabbath is a 'holy' day on which one gives up on matters of the world. It was noted above that one effect of the legalistic approach to Sabbathkeeping was that it created feelings of guilt when rules and regulations were not kept, with negative consequences for the mental health of that person. Such feelings of guilt can have further negative consequences because, ironically, they can generate the desire for more rules that will prevent future failure to keep to the practice. There is then little inherent appreciation of the practice itself, because the focus shifts to rules that have to be obeyed.

In contrast, Sabbath-keeping is about a lightness of being and a celebration of beauty, especially because it refreshes, restores and heals. It is, therefore, to be celebrated for its transformative power that brings life to flourish. This is shown, for example, by a growing number of studies that revealed how Sabbath-keeping has a positive effect on mental health (cf., e.g., Diddams et al. 2004; Speedling 2019:1382-1400; Superville, Pargament \& Lee 2014). Diddams et al. (2004) found this so important that they define the practice in terms of its transformative nature. They write:

[W]e do not define Sabbath-keeping as merely a cessation from daily labor or activities, or a photo negative of our everyday lives. Instead, Sabbath-keeping broadly defined consists of intentional period of time set aside to restore equilibrium to the mind, spirit and body where a person may use his or her religious belief system to reflect on life's personal and spiritual meaning. (p. 3)
This remark relates Sabbath-keeping to mind, spirit and body, involving in this spiritual practice also the somatological aspect. Valuable also in this definition is the notion of Sabbath-keeping as restoring 'equilibrium' and as an 'intentional' period of time. It reflects choosing and committing, but also a balanced, mature existence. The psychological impact of the practice also affects the concrete, bodily existence. The special holy nature of Sabbath-keeping is not merely a spiritual, religious matter, but has to do with the bodily and physical aspects. It questions the trend in religious settings toward segmentation, that is, to keep life domains apart from their religious activities instead of finding a balance between them. ${ }^{25}$ Sabbath-keeping is thus depicted as a holistic practice that has to do with a life in which the spiritual practice is not dualistically separated from the worldly practice, but encompasses both. ${ }^{26}$ It ultimately integrates in a comprehensive manner all the dimensions of human existence, including body.

These restorative positive dimensions are evident in various matters, which require more explanation now.

\section{Resting in liturgy}

Sabbath-keeping is about resting, the positive counterpart of not working. It is the explicit object of the commandment to keep the Sabbath by resting. Resting is about rediscovering and regaining equilibrium. Resting does not simply happen when one does not work. Resting can be stressful, especially if there is not a complete distancing from a stressful workplace from which one is resting. This is one reason why the Sabbath rest has to do with an explicit religious and liturgical aspect: Sabbath-keeping is about seeking to find rest in the divine presence in liturgy, shifting attention from being occupied by weekly activities.

In Jewish contexts, attending meetings in the synagogue is a fixed part of Sabbath-keeping. In Christian contexts, Sunday worship is also inextricably linked with worship and devotional action. The occasional, indirect experience of God's provision and care during the working week is replaced by a more concentrated and direct encounter with God in worship where the divine word is heard and the sacrament is experienced.

Resting is then a matter of attending to spiritual desires of the heart and mind in a manner that does not happen during the week, but also to grow in a habit that is different from those at other days and places. ${ }^{27}$ Sabbath-keeping is, therefore, about resting in God - in a manner that celebrates the day thankfully and with gratitude simply because it is a covenantal gift of grace. Resting means being liberated from the urge to perform, or from the desire to earn divine grace.

25.For Sabbath-keeping this means that 'actively disengaging from work to focus on other areas of one's life can help promote a more balanced lifestyle, providing greater psychological resilience' (Diddams et al. 2004:4).

26.See Dein and Loewenthal (2013) for an analysis of the mental health benefits of Sabbath-keeping amongst orthodox Jews.

27.For this section, cf. the discussion about Sabbath models in Diddams et al. (2004:4-5). 
Resting intensifies the beauty of the Sabbath because it is about the understanding that the Sabbath 'is God's sign of unmerited favour in his creation and redemption of the world (covenant)' ${ }^{28}$ This aspect is very valuable because it explains that Sabbath-keeping is the result of its inherent beauty. It is a practice that refreshes, that is, not done out of compulsion. It is done because it makes life meaningful, addresses fundamental spiritual needs and brings healing in relationship with self, others and the divine.

\section{Resting with others}

Resting does have even more meaning: Sunday worship is about resting in God, but it is also a communal practice. It means resting together with and in company of others, ${ }^{29}$ that is, about a community that nurtures and enjoys the day of rest as a day of beauty. ${ }^{30}$ Sabbath observance has a profoundly social and communal character. The communal nature of Sabbath observance means seeking to be with others in communal activities like sharing a meal and participating in meaningful rituals.

The beauty of this gathering with others is that it takes place in a relaxed atmosphere, sharing togetherness in a simple or lavish manner. It becomes a matter of abundance: Bass (1997:87) characterised the meal as time 'wasted' together in the context of no fixed agenda. Not only do others help us to relax, to set aside our work, but the practice also assists in bonding, expressing affection and forgiving each other.

The communal gathering with others can also be understood more specifically from the perspective of family: Sabbath has been a day for social bonding with close relatives and friends. Sabbath-keeping may include speaking with them about or reflecting on spiritual matters, but it is also about the mundane, about everyday experiences, about being at rest or refreshed on the most basic level of existence. It is about more than building up healthy relationships, about the joy of finding ultimate meaning in the intimacy of one's closest associates.

It reminds practitioners that they share a common humanity with all people and that this shared humanity transcends all the traditional, self-centred boundaries set up within society. It brings about an understanding that life is not about oneself and one's own ambitions and career, but about a shared existence with others. The common humanity means sharing with others in all the rights and privileges of human

\section{Diddams et al. (2004:6) noted that 'God's grace is not made conditional on man's} obedience to God's commandments (contract)'

29.On the Sabbath 'friends and relatives come together join together for meaningful discourse concerning important life issues and it is a focus for emotional expression' (Dein \& Loewenthal 2013:1398). The spiritual discussion can focus on socia challenges and concerns, especially when important values are at stake. For example, those considering how more completely to embrace Sabbath should give close attention to the economic pressures that make a day of rest far more possible for some than for others. This will serve the cause for social justice: spiritua forme that ho othis. This will serve the cause for social justice: spiritual at a living wage and time for rest and worship also (see also Vorster 2011).

30.Bass $(2005: 26)$ notes, ' $t$ t hose who have embraced the practice of Sabbath observance have not done so in order to induce Christian growth; they have rather been moved by obedience, or by exhaustion, or by attraction to the beauty of the Sabbath and the life-patterns that emerge among those who observe it'. existence. ${ }^{31}$ This is why Sabbath-keeping also promotes acts of mercy and compassion. The fruit of one's labour as divine gift is to be shared with all. It is striking that the ministry of Jesus stands out in its emphasis on how acts of mercy are allowed on and surpassed by Sabbath-keeping. To keep the Sabbath is a part of doing good (cf. Mt 12:1-14).

\section{Resting in play}

Rest can also refer to being on one's own: the experience of rest can range from deep, restful sleep to reading to engage in playful recreation or to activities such as walking, experiencing nature. One can also be at rest in leisure activities and play. ${ }^{32}$ For some, play can be experienced as participating in or watching sport. For others, it is about doing an activity with a child (like building a puzzle). It may include experiencing an art exhibition or wildlife in the bush', bird watching or participating in some kind of conservation. For others, an interest or a hobby can be undertaken in this time.

All this presents an opportunity to relearn play that adults unlearn pretty early. There are rare moments when it re-emerges, perhaps in the bedroom with a lover or in jest with friends. Play encourages people to take themselves, their circumstances and even the world a little less seriously. Play is different from work. It is frivolous, without an expected outcome. It offers no reward except the reward of participating in it. Play is a notion that reminds one of the true nature of the Sabbath as the divine, restful and joyful response to the beauty as a divine gift to humanity. Sabbath-keeping reflects play in being enjoyed for what it is, not for what it achieves.

\section{Resting in joy}

Resting in God, with others and in play means overcoming anxiety, to rediscover joy. In Sabbath-keeping, one is liberated from the urge to perform, and rejects being controlled by one's labour or to find one's identity in work. It is ultimately about a lightness of being, of trusting exclusively on the divine provision (Bass 1997:86). ${ }^{33}$ It represents the pronouncement in the Sermon on the Mount about anxiety (Diddams et al. 2010):

$[B] y$ worrying, people replace God with themselves as a central source of hope which will decrease feelings of competence in resolving life's discrepancies. Spending the Sabbath day worrying about future personal issues disregards its covenantal nature by forgetting that the Sabbath reflects the sign of God's mercy and blessing to creation. (pp. 7-8)

31.This means asking for humane and fair labour practices for all. Sabbath-keeping challenges faith communities to promote fair labour practises so that all may have the opportunity to a fulfilled life (Vorster 2011:187).

32.See Kessler (2012:6). He notes recent calls by Protestant churches that deviated from the traditional lack of interest in resting on a Sunday, and began to promote the 'benefit of leisure as an essential part of Sunday sanctification'. According to Bass $(2005: 30)$, 'But the holiness of the Sabbath is also made manifest in the joy have sexual intercourse on Shabbat. Taking a walk, resting, talking with loved ones, reading - these are good'.

33.For helpful literature and a discussion on anxiety, see https://www.oxford.anglican. $\mathrm{org} / \mathrm{mission}$-ministry/ministry/cmd/resources-for-personal-development/ keeping-the-sabbath/. 
Sabbath-keeping has been linked to a spirit of joy by Heschel (1951:30) who wrote, ' $[t]$ he Sabbath is no time for personal anxiety or care, for any activity that might dampen the spirit of joy'. The biblical narrative reflects this joy in Genesis 2 with the remark that God stopped from creation so as to experience and enjoy what God had made. Sabbath thus allows practitioners to observe, to experience, to discover and to seek new understanding without the angst and pressure of having to achieve something. With such a spirit, life is experienced with joy, but in this case, the joy is for its own sake, not an instrument for ulterior gain.

\section{Earth}

The above comments reinforce and underline more traditional insights of Sabbath-keeping. In recent times, reflections on Sabbath-keeping have taken on new themes and, thus, provided new forms of Sabbath-keeping. One of the more striking forms is closely linked with the Sabbath as part and climax of the creation narrative. The joy with which God is said to view the world, and the place of humanity as sustainers of the earth, contributed to a strong ecological awareness amongst those who desired to practise Sabbathkeeping.

This perspective responds to the way the earth has been damaged and destroyed through the activities of humanity and, especially to the abuse of the earth because of a materialist lifestyle. The consequence of human striving and of endless desire in consumerist society to own more, and to build monuments of success, has had devastating effects on the earth, leaving it dry and barren. The Sabbath's rest is relevant here not only for people, but also for the world.

When one considers the role of Sabbath within the context of creation, it also relativises the focus on self-interest and selfcentredness. Taylor (2009) noted that the Sabbath command is not only for the benefit of humankind:

Sabbath is not only God's gift to those who have voices to say how tired they are; Sabbath is also God's gift to the tired fields, the tired vines, the tired vineyard, the tired land. (p. 132)

This is most evident in the Jubilee year that has to be kept every 50th year (Lv 25:10-11).

The devastation of the earth and its need to rest from such abuse has become so extreme that one could describe it as ecocide. ${ }^{34}$ God provides for humanity's need, even for the needs of the earth's animals, all of whom live in the providence of God's care. The abuse of earth and squander of time affect not only them, but also neighbours, those whom they enslave and indeed the whole biosystem that supports their living (Taylor 2009:132). Even earth's inhabitants who have no rights (animals, plants and the economically

34.On this term and its serious nature, see Vorster (2015). He writes (Vorster 2015:882), 'Humankind is called to be a steward in caring for God's creation. In the execution of this calling it is responsible to God and cannot act as a king on its own. Its duty will be to unfurl the beauty and the goodness of nature and to combat the remnants of sin that distorted the goodness of creation due to the Fall of humankind. A Christian ethics of life will entail that the relation between humankind and nature should be one of stewardship in service of God'. He offers humankind and nature should be one of stewardship in service of God'. He offers
some practical guidelines on how to deal with ecocide at the end of his article. enslaved) have God-given rights enshrined in Scripture. Sabbath is a guardian of such rights, illuminating their responsibilities towards each other.

Another perspective on the relationship of Sabbath-keeping with the earth has to do with resting. Resting can also involve the habit of observing the earth and its beauty. In doing so, one is connected with the earth. It is about a restful form of existence in the divine creation. It is not about abandoning things or a reclusive lifestyle, but rather about discerning one's place and time as a gift in itself. Taylor (2009) stated:

$[I] n$ the eyes of the world, there is no payoff for sitting on the porch. A field full of weeds will not earn anyone's respect. If you want to succeed in this life (whatever your 'field' of endeavour), you must spray, you must plow, you must fertilize, you must plant. You must never turn your back. Each year's harvest must be bigger than the last. That is what the earth and her people are for, right? Wrong god. In the eyes of the true God, the porch is imperative - not every now and then but on a regular basis ... (p. 133)

There is finally, another perspective that reveals the link of Sabbath-keeping with care. The Earth needs rest also so as to allow the spontaneous (or God given) growth to emerge $e^{35}$ (Olson 2008:21). Matthew 6:26 reflects the divine care and sustenance of the earth, 'Look at the birds of the air; they do not sow or reap or store away in barns, and yet your heavenly Father feeds them' (NIV). In the design of the Creator, all created things need rest, the exercise of freedom and the reminder that 'the earth is the Lord's and everything in it' (Ps 24:1) (Taylor 2009:21-23). Sabbath-keeping as a practice must, therefore, include an awareness of and involvement with the earth. This involves an appreciation for the beauty of the earth as an access to wonder, regarding it from a divine perspective as God's, and the care for the earth which also needs to rest from providing for our ever increasing needs.

This perspective develops a key characteristic of the Sabbath in Biblical material. Sabbath is closely linked with creation in a physical sense of the word, delighting in its beauty, but also being concerned and caring for its well-being. ${ }^{36}$

\section{Conclusion}

Sabbath-keeping is indeed about the important need to rest from the challenges of daily labour, but it is ultimately not merely a coping mechanism for those who are physically and 35. Olson (2008:21) writes, "[ $t$ ] e Sabbath commandment's concern for the humane
treatment of animals embodies a larger ecological concern that extends beyond animals to the land itself'.

36.Sabbath-keeping is relevant for care of the earth in multitude ways: Cafferky (2015) linked it with the theological roots of sustainable development when he showed how Sabbath is to be linked with creation and is also the substance and symbol of God's care for this earth. Hartman (2011:47-64), for example, argues that three characteristics of Sabbath-keeping prompt a simple lifestyle, referring to the theological insight of its theocentric and eschatological perspectives and, more practically, its promotion of a simpler life style, including its environmentally salutary effects. The latter facet of Sabbath-keeping has become prominent in salutary effects. The latter facet of Sabbath-keeping has become prominent in recent times. Vorster (2011), casting the net wider, also focused on the implied ethical principles of the manna episode in Exodus 16 for understanding its ongoing relevance. He lists the principle of labour, rest, sharing, responsible consumption, the protection of creation and of remembrance of God's concern for hy and creation as matters for consideration. By attending to these principles, contemporary consumerism and ecological devastation could be redressed by a relevant Sabbath-keeping. 
emotionally tired and exhausted. It is about a spiritual practice that restores and refreshes on a deeper level that has to do with the quest for spiritual maturity and growth. It helps one to reflect on a complex configuration of issues, that is, on priorities, values, on the role of labour in human existence, on the rhythm of life, on living in time and space and on the nature of life beyond work. The day, thus, becomes relevant on many levels, such as, for example, economics and management and thus obtains a comprehensive and holistic character. ${ }^{37}$ Even when celebrated as a secular day of rest, the lightness of a weekly respite has an inherent beauty and promotes feelings of joy. The challenge for religious communities then is to engage in a practice that brings one to celebrate life in all its beauty - daily life and labour included, and to liberate the practice of deadening externalism.

Sabbath-keeping is a celebration of the God-given beauty of life, creation and work. Its beauty is seen in its place in the divine acts of creation (Gn 1-2) and recreation in the Exodus to the promised land. It is about participating in the goodness that permeates and reflects those divine actions. It should, therefore, be devoid of legalism and moralism: after all, the practice speaks of the limitations of work and of consumption, and calls for trust in the divine providence. A leading test for an authentic Sabbath-keeping is whether it helps one to recognise and experience the goodness and beauty of life - to the extent that one is conscious of the extraordinary in the ordinary, the ethereal in the mundane.

The ancient Sabbath practice brings a sense of balance in life with its discernible rhythm of rest and work in which rest is just as important, just as valued, as work. On a deeper level, Sabbath-keeping also provides a valuable corrective for people of faith, reminding them that the world is not dependent on humanity, but is dependent on God's gracious provision. In a contemporary setting, Sabbath-keeping is not about an exodus from Egypt or about not gathering manna in the desert. Given new situations and contexts in contemporary societies, one has to distil the spiritual nature of Sabbath-keeping in biblical texts to find new ways of celebrating the day of rest. Given the ravages that resulted from contemporary ways of living, Sabbath-keeping has the potential to restore human dignity and to work towards the restoration of creation: it can transform the anxiety that the consumerist society instils in people and bring them to rediscover their dignity as human beings. It can heal interpersonal relationships by inspiring acts of mercy and compassion. Those who are victims of consumerism and of the destruction of the planet will be liberated in new ways to find that which gives true fulfilment, to engage with the earth in order to appreciate its beauty and to oppose what destroys and pollutes it.

Once one discovers the potential of Sabbath-keeping to bring new life, the commandment cannot be a burden. It then speaks about a love affair that brings healing, inspiration and true joy. It ultimately reflects the notion of paradise that is so prominent in the eschatological expectations of the Judeo-Christian traditions. The richness of the 'eternal' Sabbath is not only a promise of the future eschaton, but it is already tangible in the celebration of the Sabbath.

\section{Acknowledgements Competing interests}

The authors declare that they have no financial or personal relationships that may have inappropriately influenced them in writing this article.

\section{Authors' contributions}

G.M. wrote the original draft for his Master's degree under the supervision of P.G.R.d.V. This was subsequently extensively reconceptualised, further researched and rewritten by P.G.R.d.V., in co-operation with G.M.

\section{Ethical considerations}

This article followed all ethical standards for research without direct contact with human or animal subjects.

\section{Funding information}

This research received no specific grant from any funding agency in the public, commercial or not-for-profit sectors.

\section{Data availability}

Data sharing is not applicable to this article as no new data were created or analysed in this study.

\section{Disclaimer}

The views and opinions expressed in this article are those of the authors and do not necessarily reflect the official policy or position of any affiliated agency of the authors.

\section{References}

Barnes, K., 2013, 'Biblical wisdom for the workplace', Paper Read at a Conference on Reconnecting Faith and the Workplace, Derby. Cf., viewed 15 April 2021, from https://www.researchgate.net/publication/291312660_Biblical_Wisdom_for the_Workplace.

Bass, D.C., 1997, 'Keeping Sabbath', in C. Dykstra \& D. Bass (eds.), Practicing our faith: A way of life for a searching people, John Wiley, San Francisco, CA.

Bass, D.C., 2000, Receiving the day: Christian practices for opening the gift of time, John Wiley, San Francisco, CA.

Bass, D.C., 2005, 'Christian formation in and for Sabbath rest', Interpretation 59(1), 25-37. https://doi.org/10.1177/002096430505900104

Brueggemann, W., 2014, Sabbath as resistance. Saying no in a culture of now, Westminster John Knox, Louisville, KY.

Cafferky, M.E., 2012, 'Sabbath and management, theology and application', Paper Read at the Christian Business Faculty Association, s.l., viewed 20 April 2021, from https://www.researchgate.net/publication/281784265_Sabbath_Management Theology_Application.

Dein, S. \& Loewenthal, K.M., 2013, 'The mental health benefits and costs of Sabbath Observance among Orthodox Jews,' J Relig Health 52, 1382-1390. https://doi.org/10.1007/s10943-013-9757-3

De Villiers, P.G.R. \& Marchinkowski, G., 2020a, 'The rediscovery of spiritual practices in Protestantism', Stellenbosch Theological Journal 6(1), 429-456. https://doi.org/10.17570/stj.2020.v6n1.a22

De Villiers, P.G.R. \& Marchinkowski, G., 2020b, 'Sabbath-keeping and Sunday observance as spiritual practice', Stellenbosch Theological Journal 6(2), 175-200. https://doi.org/10.17570/stj.2020.v6n2.a8 
De Villiers, P.G.R. \& Marchinkowski, G., 2021, 'Sabbath-keeping in the Bible from the perspective of biblical spirituality', HTS Teologiese Studies/Theological Studies 77(2), a6755. https://doi.org/10.4102/hts.v77i2.6755

Diddams, M., Surdyk, L.K. \& Daniels, D., 2004, 'Rediscovering models of Sabbathkeeping: Implications for psychological well-being', Journal of Psychology and Theology 32(1), 3-11. https://doi.org/10.1177/009164710403200101

Earle, A.M., 1909, The Sabbath in Puritan New England, Charles Scribner, New York, NY. Hartman, L., 2011, 'Christian Sabbath-keeping as a spiritual and environmental practice', Worldview 15, 47-64. https://doi.org/10.1163/156853511X553769

Heschel, A.J., 1951, The Sabbath. Its meaning for modern man, Farrar, Straus and Giroux, New York, NY.

Kessler, V., 2012, 'The Sabbath as a remedy for human restlessness', In Die Skriflig 46(2), 1-8. https://doi.org/10.4102/ids.v46i2.61

Marks, L.D., Hatch, T.G. \& Dollahite, D.C., 2017, 'Sacred practices and family processes in a Jewish context: Shabbat as the weekly family ritual par excellence', Family Process 57(2), 1-13. https://doi.org/10.1111/famp.12286

Marques, J., 2005, 'Spirituality in the workplace: Developing an integral model and a comprehensive definition', Journal of American Academy of Business 7(1), 81-91.

Marschke, E., Preziosi, R. \& Harrington, W., 2009, 'Professionals and executives support a relationship between organizational commitment and spirituality in the workplace', Journal of Business and Economic Research 7(8), 33-48. https://doi. org/10.19030/jber.v7i8.2320

McCormick, F.R., 1994, 'Sabbath rest: A theological imperative according to Kar Barth', Journal of the American Academy of Religion 62(2), 539-552, viewed 13 April 2021, from http://www.jstor.org/stable/1465277.

McLaughlin, B., 2017, 'Recovering the Sabbath: Sunday observance as a universal human right and civic cooperationism', Lumen et Vita 8(2017), 26-37.

McMahon, D.M., 2018, 'From the Paleolithic to the present: Three revolutions in the global history of happiness' in E. Diener, S. Oishi, \& L. Tay (eds.), Handbook of wellbeing, DEF Publishers, Salt Lake City, UT.

Olson, D.T., 2008, 'Sacred time: The Sabbath and Christian worship', in C.M. Bechte (ed.), Touching the altar, pp. 1-34, Eerdmans, Grand Rapids, MI.

Orr, R., s.a., 'Old Testament Laws: From Sunday to Sabbath: The Puritan origins of modern seventh-day Sabbatarianism', in Grace Communion International, viewed 20 February 2021, from https://archive.gci.org/articles/from-sunday-to-sabbaththe-puritan-origins-of-modern-seventh-day-sabbatarianism/.
Parker, K., 1984, 'Thomas Rogers and the English Sabbath: The case for a Reappraisal', Church History 53(3), 332-347. https://doi.org/10.2307/3166273

Peterson, C., 2006, 'Strengths of character and happiness: Introduction to special issue.' Journal of Happiness Studies 7(3), 289-291.

Quartey, M., 2018, 'Why don't we stone Sabbath breakers anymore?', The Spectrum 16 August 2018, viewed 18 April 2021, from https://spectrummagazine.org/ article/2018/08/16/why-don $\% 25 \mathrm{E} 2 \% 2580 \% 2599$ t-we-stone-sabbath-breakersanymore.

Selligman, M.E.P., 2002, Authentic happiness, Free Press, New York, NY.

Shields, M., 2006, 'Unhappy on the job', Health Reports/Statistics Canada, Canadian Centre for Health Information 17, 33-37.

Smith-Gabai, H. \& Ludwig, F., 2011, 'Observing the Jewish Sabbath: A meaningful restorative ritual for modern times', Journal of Occupational Science 18(4), 347-355. https://doi.org/10.1080/14427591.2011.595891

Specter, T.P., 2018, Positive Shabbat dinner: An effective positive intervention to increase well-being, Master of Applied Positive Psychology (MAPP) Capstone Projects, p. 145, s.n., s.l.

Speedling, B., 2019, 'Celebrating Sabbath as a holistic health practice: The transformative power of a sanctuary in time', Journal of Religion and Health 58(4), 1382-1400. https://doi.org/10.1007/s10943-019-00799-6

Superville, D.J., Pargament, K.I. \& Lee, J.W., 2014, 'Sabbath keeping and its relationships to health and well-being: A mediational analysis', International Journal for the Psychology of Religion 24(3), 241-256. https://doi.org/10.1080/10508619.2013.8 37655

Taylor, B.B., 2009, An altar in the world. A geography of faith, Harper Collins, New York, NY.

Vorster, J.M., 2011, “"Go out and gather each day ...": Implications of the ethics of Exodus 16 for modern consumerism', Koers 76(1), 171-192. https://doi. org/10.4102/koers.v76i1.12

Weeks, L.B., 1981, 'The Scriptures and Sabbath Observance in the South', Journal of Presbyterian History 59(2), 267-284.

Waaijman, K., 2002, Spirituality. Forms, foundations, methods, Peeters, Leuven, pp. 869-945.

Waaijman, K., 2006, 'What is spirituality?', Acta Theologica Supplementum 8, 1-18. 